\title{
Studi awal tanin dari kulit kayu Acacia auriculiformis A. Cunn. ex Benth. dari hutan tanaman industri untuk bahan penyamak kulit
}

\section{Study of tannin from bark of Acacia auriculiformis A. Cunn. ex Benth. from industrial plantation forest for tanning agent}

\author{
Sri Mutiar ${ }^{1 *}$, Anwar Kasim², Emriadi ${ }^{3}$, Alfi Asben² \\ ${ }^{1}$ Program Pascasarjana, Universitas Andalas, Padang, Indonesia \\ ${ }^{2}$ Fakultas Teknologi Pertanian, Universitas Andalas, Padang, Indonesia \\ ${ }^{3}$ Fakultas Matematika dan Ilmu Pengetahuan Alam, Universitas Andalas, Padang, Indonesia \\ *Penulis korespondensi. Telp. 085363055878 \\ E-mail: srimutiar@unidha.ac.id
}

Diterima: 8 Juni 2018

Direvisi: 13 September 2018

Disetujui: 22 Oktober 2018

\begin{abstract}
This study aims to determine the tannin content and extraction method of the content and levels of tannin from the bark of Acacia auriculiformis A. Cunn. ex Benth. The bark is obtained from PT. Arara Abadi. The extract methods are water bath, ultrasonic bath, autoclave, reflux, and microwave. The tannin extract produced was applied as a vegetable tanning agent. The extract which is the best yield of the method used. The results showed that the highest yield was obtained by the autoclave method which was $29.65 \%$. The results of chemical analysis of the extract produced were $52.79 \%$ tannin content, $62.40 \%$ water soluble materials. Application of the tannin extract as a vegetable tanning agent on goat skin was carried out chemical analysis, observation of physical and organoleptic properties. The quality of tanned skin was seen from the chemical properties, i.e. water content of $15.02 \%, 3.20 \%$ fat content, $3.44 \%$ ash content, $3.57 \%$ water soluble substances, $43.79 \%$ raw skin substances, $30.98 \%$ bonded tannins, $70.74 \%$ degree of tannage. Observation of physical properties of tanned skin were tensile strength $254.21 \mathrm{~kg} / \mathrm{cm}^{2}, 63.95 \%$ elongation at break, $9.27 \mathrm{~mm}$ zwik resistance/crack (non-broken nerf), thickness $0.9 \mathrm{~mm}$, and brown color. A. auriculiformis bark extract contains tannins and potential as tanning agent.
\end{abstract}

Keywords: Acacia auriculiformis, extraction, leather, tannin

\begin{abstract}
ABSTRAK
Penelitian ini bertujuan untuk mengetahui kandungan tanin dan metode ekstraksi terhadap karakteristik dan kadar tanin dari kulit kayu Acacia auriculiformis A. Cunn. ex Benth. Kulit kayu diperoleh dari HTI PT. Arara Abadi. Metode ekstrak yang digunakan water bath, ultrasonic bath, autoclave, refluks dan microwave. Ekstrak tanin yang dihasilkan diaplikasikan sebagai bahan penyamak nabati. Ekstrak yang digunakan adalah rendemen tertinggi dari metode yang digunakan. Hasil penelitian menunjukkan bahwa rendemen tertinggi diperoleh dengan metode autoclave yaitu 29,65\%. Hasil analisis kimia dari ekstrak yang dihasilkan kadar tanin adalah 52,79\%, bahan larut air $62,40 \%$. Aplikasi ekstrak tanin sebagai bahan penyamak nabati menggunakan kulit kambing dilakukan analisis kimia, pengamatan sifat fisik dan organoleptis. Kualitas kulit tersamak ditinjau dari sifat kimia diantaranya kadar air 15,02\%, kadar lemak 3,20\%, kadar abu 3,44\%, kadar zat larut air 3,57\%, kadar zat kulit mentah 43,79\%, kadar tanin terikat 30,98\% dan derajat penyamakan 70,74\%. Pengamatan sifat fisik kulit tersamak yaitu kekuatan tarik 254,21 kg/cm², kemuluran 63,95\%, ketahanan zwik/keretakan 9,27 mm (nerf tidak pecah), ketebalan 0,9 mm, warna coklat. Ekstrak kulit kayu A. auriculiformis mengandung tanin dan berpotensi untuk digunakan sebagai bahan penyamak kulit.
\end{abstract}

Kata kunci: Acacia auriculiformis, ekstraksi, kulit tersamak, tanin 


\section{PENDAHULUAN}

Pengembangan Hutan Tanaman Industri (HTI) dilakukan untuk menyediakan bahan baku kayu untuk pemenuhan (supply) bahan baku industri pulp dan kertas. Produksi kayu dari HTI menyisakan limbah berupa kulit kayu yang belum termanfaatkan. Sementara pada kulit kayu tersebut mengandung senyawa tanin yang dapat dimanfaatkan. Menurut Sjotrom (1998), jumlah kulit kayu berkisar antara 10-15\% dari berat pohon. Berdasarkan data, tebangan dan produksi PT. Arara Abadi tahun 2015 adalah $3.691 .030 \mathrm{~m}^{3}$, jika diperhitungkan jumlah limbah kulit kayu berkisar 369.103-553.654 $\mathrm{m}^{3}$. Dengan demikian, ketersediaan kulit kayu HTI ini berpotensi untuk diolah dan dijadikan sebagai bahan penyamak kulit. Saat ini, Indonesia mengimpor bahan penyamak kulit berupa mimosa yang diperoleh dari ekstrak tanaman akasia serta quebraco yang diekstrak dari tanaman Quebraco lorenzi.

Menurut Suseno et al. (2014), kulit kayu terdiri dari senyawa makro molekul (polisakarida dan lignin) sebagian meliputi bahan organik dan non organik yang tersusun atas senyawa ektraktif. Senyawa ektraktif terdapat kandungan senyawa terpena, asam alifatik, dan fenolik. Salah satu senyawa fenolik yang banyak dimanfaatkan adalah senyawa tanin. Ekstraksi tanin dapat dilakukan dengan menggunakan berbagai pelarut. Menurut Haroun et al. (2013), tanin dapat dilarutkan dalam air, alkohol, aseton, tetapi tidak larut dalam benzene, kloroform, dan pelarut organik dari petroleum eter. Tanin yang dilarutkan dalam air akan bermuatan listrik negatif dan akan teroksidasi dalam larutan alkali yang berubah warna menjadi hitam.

Menurut Musa and Gasmelseed (2013), tanin adalah zat samak yang terdapat pada tumbuhan. Zat samak yang maksud adalah dapat larut dalam air sehingga dapat merubah kulit mentah menjadi kulit tersamak, tidak dapat dirusak oleh mikroorganisme, tahan dan stabil terhadap panas. Kulit tersamak memiliki kualitas yang berbeda sesuai dengan bahan penyamak yang digunakan. Menurut Kasim et al. (2012), Kasim et al. (2013), Kasim et al. (2015), dan Kasim \& Mutiar (2016), bahan penyamak nabati merupakan zat samak non mineral yang dihasilkan oleh tanaman seperti gambir, mimosa, dan kulit kayu akasia sehingga menghasilkan karakteristik dan kualitas sesuai dengan zat samaknya.

Ekstraksi tanin dilakukan memperoleh rendemen ekstrak yang tinggi. Suparno et al. (2008) menyatakan senyawa tanin bersifat polar dalam bentuk glikosidanya. Tanin juga mengendap dengan protein dan logam-logam berat. Kedua sifat ini sangat berpengaruh terhadap cara ekstraksi dan identifikasi senyawa tanin. Menurut Herminiwati et al. (2015), tanin yang terdapat pada kulit kayu akasia dapat diperoleh melalui proses ekstraksi. Selanjutnya Wina et al. (2010), Liao et al. (2015), dan Iriany (2017) menyatakan bahwa terdapat beberapa metode yang dapat digunakan untukf mengekstrak tanin, diantaranya metode waterbath, autoclave dan dengan refluks. Penggunaan berbagai metode ini bertujuan untuk mengetahui metode yang tepat untuk menghasilkan ekstrak tanin sebagai bahan penyamak kulit.

\section{BAHAN DAN METODE Bahan Penelitian}

Bahan yang digunakan adalah kulit kayu HTI dari PT. Arara Abadi, aquades, dan kulit kambing.

\section{Peralatan Penelitian}

Peralatan yang digunakan adalah timbangan analitik, sentrifuge, cabinet dryer, disc mill, saringan 70 mesh, waterbath Memmert WNB 29, refluks, microwave Sharp R-222Y-S, autoclave Hirayama Hiclavev-85, kertas saring, dan spektrofotometer UV 1800.

\section{Metode Penelitian \\ Persiapan sampel}

Sampel yang digunakan adalah kulit kayu $A$. auriculiformis. Kulit kayu yang digunakan adalah kulit kayu matang panen yang berasal dari HTI PT. Arara Abadi Riau. Mekanisme persiapan sampel mengacu kepada metode Mahdi et al. (2006) dengan modifikasi. Kulit kayu tersebut dipotong kecil-kecil dengan ukuran 0,5-1,0 cm dan dikeringkan. Selanjutnya dihaluskan menggunakan disc mill dan disaring dengan saringan 70 mesh. Selanjutnya dipersiapkan untuk proses ekstraksi.

\section{Analisis Kimia Kulit Kayu A. auriculiformis}

Penentuan kadar air. Penentuan kadar air dilakukan dengan metode TAPPI T264 om-88. Sampel dipanaskan pada suhu $105^{\circ} \mathrm{C}$ sampai berat konstan. Selanjutnya dilakukan perhitungan untuk mengetahui persen kadar air dalam bahan dengan rumus berikut.

Kadar air $(\%)=\frac{(\text { Berat awal-Berat kering) }}{\text { Berat kering }} \times 100 \%$ 
Kadar abu. Penentuan kadar abu dilakukan dengan mengunakan furnace suhu $500^{\circ} \mathrm{C}$ selama 3 jam. Kemudian melakukan penimbangan zat yang tertinggal $(\mathrm{abu})$ setelah proses pembakaran tersebut dengan rumus:

Kadar abu $=\frac{\text { Berat abu }}{\text { Berat sampel }} \times 100 \%$

Kadar larut air. Bahan ditimbang sebanyak $30 \mathrm{~g}$ di dalam erlenmeyer dengan volume $1000 \mathrm{ml}$ dan ditambahkan $600 \mathrm{ml}$ aquades. Campuran diaduk dengan menggunakan pengaduk magnet selama 20 menit. Campuran disaring dengan mengunakan kertas saring, filtrat ditampung sampai $200 \mathrm{ml}$. Filtrat berikutnya diambil sebanyak $50 \mathrm{ml}$ untuk menentukan persentase residu. Filtrat dikeringkan hingga didapatkan residu. Kadar bahan larut air dihitung dengan rumus berikut.

Kadar bahan larut air $=\frac{\text { Berat residu } \times 12}{\text { Berat kering }} \times 100 \%$

Kadar bahan bukan tanin. Dari bahan penentuan bahan larut air, selanjutnya filtrat diambil 2 x $75 \mathrm{ml}$ ke dalam 2 erlemeyer $300 \mathrm{ml}$. Kemudian ditambahkan 6,5 g tepung kulit dan dishaker selama 20 menit. Tepung kulit disaring menggunakan corong porselen dengan bantuan pompa hisap sehingga didapat filtrat. Tepung kulit tersebut dimasukan ke dalam erlemeyer kedua yang didalamnya berisi filtrat. Tepung kulit tersebut diurai dan di-shaker selama 15 menit. Campuran disaring melalui corong porselen dengan bantuan pompa hisap hingga didapat filtrat. Kedua filtrat yang diperoleh disatukan dan disaring dengan kertas saring dan cukupkan menjadi $150 \mathrm{ml}$. Filtrat sebanyak $50 \mathrm{ml}$ dan tentukan berat residunya. Kadar bahan bukan tanin dihitung dengan rumus berikut.

Kadar bahan bukan tanin $=\frac{\text { Berat residu } \times 12}{\text { Berat kering }} \times 100 \%$

Kadar tanin. Kadar tanin ditentukan dengan perhitungan berikut.

Kadar tanin $=$ Kadar bahan larut dalam air - kadar bahan bukan tanin

\section{Metode Ekstraksi}

Ekstraksi dilakukan menggunakan aquades, perbandingan air dengan bahan 1:20. Proses ektraksi air divariasikan 5 macam ektraksi sebagai berikut: a. Ekstraksi menggunakan waterbath pada suhu $100^{\circ} \mathrm{C}$ selama 40 menit.

Sampel yang telah dicampurkan dengan air dipanaskan dalam waterbath suhu $100^{\circ} \mathrm{C}$ selama 40 menit. Dilakukan pengadukan beberapa kali agar tidak terjadi pengendapan.

b. Ekstraksi menggunakan ultrasonic bath dengan waktu 30 menit.

Sampel yang telah dicampurkan dengan air kemudian dimasukkan ke dalam microwave selama 30 menit. Ekstraksi menggunakan autoclave dengan waktu 40 menit.

c. Ekstraksi autoclave.

Sampel yang telah dicampurkan dengan air kemudian dimasukkan ke dalam autoclave selama 40 menit suhu $121^{\circ} \mathrm{C}$. Ekstrak disaring untuk memisahkan filtrat dengan residu.

d. Ekstraksi menggunakan refluks selama 4 jam. Sampel yang telah dicampurkan dengan air kemudian dipasangkan pada alat refluks. Proses ini dilakukan selama 4 jam.

e. Ekstraksi menggunakan microwave dengan waktu 3 menit.

Sampel yang telah dicampurkan dengan air kemudian dimasukkan ke dalam microwave selama 3 menit dengan daya $100 \mathrm{~W}$. Masingmasing ekstrak disaring untuk memisahkan filtrat dengan residu. Selanjutnya filtrat dievaporasi sampai diperoleh ekstrak pekat. Ektrak tanin dikeringkan pada suhu $105^{\circ} \mathrm{C}$. Waktu ekstraksi dihitung setelah suhu tercapai untuk perlakuan A, B, dan D. Filtrat dipekatkan dengan vacuum rotary evaporator dengan pemanasan pada suhu $60^{\circ} \mathrm{C}$, sehingga diperoleh ekstrak tanin. Selanjutnya dihitung rendemen ekstrak dengan rumus:

Rendemen $(\%)=\frac{\text { Berat ekstrak }}{\text { Berat sampel }} \times 100 \%$

\section{Penyamakan Kulit}

Metode penyamakan kulit kambing modifikasi penyamakan kulit dari Balai Besar Kulit, Karet, dan Plastik (BBKKP) Yogyakarta yaitu, kulit yang digunakan adalah kulit kambing kering awet garam. Persiapan kulit untuk disamak yang terdiri dari perendaman kulit kering, buang bulu, dan selanjutnya sampai diperoleh kulit pikel. Kulit pikel dilanjutkan dengan penyamakan kulit menggunakan bahan penyamak hasil ekstraksi tanin dengan rendemen tertinggi.

Konsentrasi bahan penyamak yang digunakan adalah $9 \%$. Selanjutnya kulit diperam selama 24 
jam, kemudian kulit dicuci untuk menghilangkan sisa zat penyamak yang masih melekat, kemudian dilakukan pengeringan dengan cara pementangan. Kulit tersamak dipersiapkan untuk dilakukan pengujian berdasarkan SNI 06-04841989.

Pengujian kimia terdiri dari kadar air, kadar lemak, kadar zat larut air, kadar zat kulit mentah, kadar tanin terikat, derajat penyamakan, dan $\mathrm{pH}$. Pengukuran kualitas fisik kulit tersamak diantaranya kekuatan tarik, kemuluran, lastibility, ketebalan, dan warna. Serta pengamatan organoleptis yang terdiri dari nerf, bagian daging, dan keadaan kulit.

\section{Analisis Data}

Analisis data menggunakan one sample $T$ test. Pengaruh dianggap nyata pada tingkat $95 \%$. Perhitungan statistik menggunakan program SPSS versi 15.0.

\section{HASIL DAN PEMBAHASAN \\ Analisis Kulit Kayu A.auriculiformis}

Data pada Tabel 1 adalah hasil analisis pendahuluan dari bubuk kulit kayu $A$. auriculiformis. Data ini digunakan sebagai dasar untuk dilakukan proses ekstrak tanin dan pemanfaatannya sebagai bahan penyamak kulit. Data menunjukkan hasil analisis kadar air, bahan larut air, kadar tanin, kadar abu dan $\mathrm{pH}$ dari bubuk kulit kayu A. auriculiformis.

Analisis ini bertujuan untuk mengetahui komponen-komponen yang terkandung pada kulit kayu. Identifikasi bahan larut air dan senyawa tanin menjadi dasar untuk dilakukan proses ekstraksi tanin. Hasil analisis bubuk kulit kayu $A$. auriculiformis menunjukkan bahan larut air $32,74 \%$ dan kadar tanin yaitu 30,84\%. Pada penelitian Hussein (2017) kadar tanin dari tanaman Akasia adalah 28,9\%. Menurut Haroun et al. (2013) terdapat berbagai macam spesies tanaman akasia dengan kandungan tanin yang berbeda pula. Kandungan tanin dari kulit tanaman Acacia tergantung kepada spesies dan tempat tumbuh dari tanaman akasia tersebut. Menurut Hussein (2017) perlu dilakukan identifikasi keberadaan tanin pada kulit kayu dengan metoda tertentu yang dimanfaatkan sebagai bahan penyamak kulit.

\section{Rendemen}

Rendemen diperoleh dari hasil ekstraksi. Ekstrak yang diperoleh dihitung sebagai rendemen yaitu persentase perbandingan hasil
Tabel 1. Analisis dari kulit kayu A. auriculiformis.

\begin{tabular}{lc}
\multicolumn{1}{c}{ Komponen } & Nilai \\
\hline Kadar air & $10,59 \pm 1,84 \%$ \\
Bahan larut air & $32,74 \pm 0,44 \%$ \\
Kadar tanin & $30.84 \pm 1,66 \%$ \\
Kadar abu & $2.06 \pm 0,29 \%$ \\
pH larutan & 6 \\
\hline
\end{tabular}

ekstrak dengan bahan yang digunakan. Penggunaan pelarut ini disesuaikan dengan sifat senyawa tanin. Menurut Ogino et al. (2008), tanin dapat larut dalam pelarut seperti air, alkohol, dan aseton. Berdasarkan pertimbangan aspek produksi maka pelarut yang digunakan adalah air. Hasil analisis statistik t-test menunjukkan terdapat perbedaan yang nyata $(\mathrm{P}>0,05)$ terhadap rendemen dan kadar tanin ekstrak. Hal ini menunjukkan berbagai metode ekstraksi menghasilkan rendemen dan kadar tanin ekstrak yang berbeda.

Pada Tabel 2 terdapat data rendemen ekstrak kulit kayu A. auriculiformis. Berbagai metode ekstraksi yang gunakan menunjukkan hasil yang berbeda. Ekstraksi tanin dilakukan dengan menggunakan pelarut air. Rendemen ekstrak menggunakan autoclave menunjukkan rendemen tertinggi yaitu $29,65 \%$. Proses ekstraksi dengan menggunakan autoclave suhu $121^{\circ} \mathrm{C}$ selama 40 menit. Hal ini menunjukkan secara berurutan rendemen ekstrak dengan metode ekstraksi menggunakan refluks selama 4 jam dan waterbath selama 40 menit. Tingginya rendemen dengan menggunakan autoclave dipengaruhi suhu yang lebih tinggi dibandingkan perlakuan lain. Dimana proses ekstraksi dipengaruhi oleh beberapa faktor diantaranya suhu. Menurut Lokeswari dan Sujatha (2011) proses ekstraksi tanin dipengaruhi beberapa faktor diantaranya pelarut, ukuran partikel, waktu, dan suhu yang digunakan.

Demikian juga halnya dengan kadar tanin ekstrak yang hasilkan, kadar tanin tertinggi diperoleh dengan metode ekstraksi menggunakan microwave. Menurut Iriany (2017), kombinasi gelombang mikro dan panas yang terdapat pada microwave pada proses ekstraksi menjadi faktor tingginya kadar bahan ekstraksi. Ekstraksi menggunakan metode ini dapat menghindari terjadinya degradasi termal pada senyawa tanin sehingga kadar tanin yang dihasilkan lebih maksimal. Penggunaan pelarut air juga menyebabkan tingginya kadar tanin, dimana tanin 
merupakan senyawa yang bersifat polar sehingga pelarut yang digunakan adalah pelarut polar seperti air. Menurut Rhazi et al. (2014) penggunaan pelarut yang dapat menyerap gelombang mikro dapat melarutkan senyawa yang diinginkan sehingga pengaruh terhadap kadar tanin yang diperoleh.

\section{Analisis Kimia Kulit Tersamak}

Data analisis kimia kulit tersamak dengan bahan penyamak ekstrak tanin dari kulit kayu $A$. auriculiformis. Ekstrak yang digunakan untuk penyamakan kulit adalah hasil ekstrak dengan metode autoclave karena rendemen dengan metode ini adalah rendemen tertinggi dengan kadar tanin 52,79\%. Pemilihan ini dilakukan berdasarkan dengan jumlah rendemen yang dihasilkan pada proses ektraksi. Tabel 3 merupakan analisis kimia kulit tersamak. Penentuan kimia kulit tersamak bertujuan untuk mengetahui tanin terikat dan derajat penyamakan dari hasil penyamakan.

Hasil analisis kimia kulit tersamak menunjukkan kualitas kulit tersamak. Hasil analisis kulit tersamak telah memenuhi standar seperti kadar air, kadar lemak, kadar zat larut dalam air dan derajat penyamakan. Derajat penyamakan merupakan jumlah bahan penyamak yang berikatan di dalam jaringan serat kolagen sehingga terjadi ikatan kimia. Menurut Kasim et al. (2012), bahan penyamak akan membentuk ikatan silang setelah proses penyamakan dilakukan sehingga dapat merubah kulit mentah menjadi lebih tahan terhadap pengaruh kimia maupun fisika.

Menurut Herminiwati et al. (2015), tanin berikatan dengan gugus-gugus aktif seperti hidroksil, karboksil dan grup amino di kolagen dalam jaringan kulit. Ikatan-ikatan yang terbentuk mengakibatkan kulit menjadi stabil. Oleh sebab itu, jumlah tanin terikat di dalam kulit tersamak berpengaruh terhadap derajat penyamakan kulit tersamak. Derajat penyamakan yang diperoleh dengan bahan penyamak ekstrak tanin dari kulit kayu A. auriculiformis adalah $70,74 \%$. Jika hasil penyamakan dibandingkan dengan standar kulit tersamak maka penyamakan kulit dengan ekstrak tanin yang digunakan pada penyamakan ini sudah memenuhi standar SNI 0253-2009.

Tabel 2. Rendemen dan kadar tanin A.auriculiformis dengan berbagai metode ekstraksi.

\begin{tabular}{|c|c|c|c|c|}
\hline \multirow[b]{2}{*}{ Metode ekstraksi } & \multirow[b]{2}{*}{ Rendemen (\%) } & \multirow[b]{2}{*}{$\begin{array}{c}\text { Bahan larut air dari } \\
\text { ekstrak }\end{array}$} & \multicolumn{2}{|c|}{ Kadar tanin } \\
\hline & & & ${ }^{a}$ Ekstrak & $\begin{array}{c}\text { bBerdasarkan bahan } \\
\text { baku }\end{array}$ \\
\hline Waterbath & $26,85 \pm 0,49$ & $76,17 \pm 0,34$ & $44,73 \pm 2,16$ & 12,01 \\
\hline Ultrasonic bath & $14,03 \pm 1,19$ & $76,73 \pm 0,63$ & $44,53 \pm 0,37$ & 06,25 \\
\hline Autoclave & $29,65 \pm 1,11$ & $62,40 \pm 0,73$ & $52,79 \pm 0,53$ & 15,65 \\
\hline Refluks & $28,03 \pm 0,12$ & $88,57 \pm 2,04$ & $53,79 \pm 2,87$ & 15,08 \\
\hline \multirow[t]{2}{*}{ Microwave } & $19,52 \pm 0,68$ & $79,10 \pm 1,44$ & $54,09 \pm 0,99$ & 10,56 \\
\hline & Uji-t $=11,961^{*}$ & & Uji-t $=22,748^{*}$ & \\
\hline
\end{tabular}

Tabel 3. Hasil analisis kimia kulit tersamak dibandingkan dengan standar.

\begin{tabular}{lcc}
\hline \multicolumn{1}{c}{ Parameter } & Kadar & SNI 06-0484-1989 \\
\hline Kadar air & $15,02 \%$ & Maks. 18 \% \\
Kadar lemak & $3,20 \%$ & $3-8 \%$ \\
Kadar abu & $3,44 \%$ & - \\
Kadar zat larut air & $3,57 \%$ & Maks. 6\% \\
Kadar zat kulit mentah & $43,79 \%$ & - \\
Kadar tanin terikat & $30,98 \%$ & - \\
Derajat penyamakan & $70,74 \%$ & Min. 25 \% \\
pH & 7 & $3,5-7$ \\
\hline
\end{tabular}


Tabel 4. Sifat fisik kulit tersamak.

\begin{tabular}{cccc}
\hline Parameter & Satuan & Angka pengamatan & Standar \\
\hline Kekuatan Tarik & $\mathrm{kg} / \mathrm{cm}^{2}$ & 254,21 & Min. 16 \\
Kemuluran & $\%$ & 63,95 & Mak. 55 \\
Lastibility & $\mathrm{Mm}$ & 9,27 & Nerf tidak pecah, min. 7 \\
Ketebalan & $\mathrm{Mm}$ & 0,9 & Min. 0,6 \\
Warna & & Coklat & Rata \\
\hline
\end{tabular}

Tabel 5. Pengamatan organoleptis kulit tersamak.

\begin{tabular}{ccc}
\hline Parameter & Pengamatan & SNI \\
\hline Nerf & Permukaan rata & licin, rata, warna rata \\
Bagian daging & Bersih dari daging & Bersih dari daging \\
Keadaan kulit & Cukup lemas & Cukup lemas \\
\hline
\end{tabular}

\section{Kualitas Fisik Kulit Tersamak}

Hasil pengukuran fisik kulit tersamak yang dilakukan diantarnya kekuatan tarik, kemuluran, lastibility, ketebalan, dan warna. Data pengamatan di tampilkan pada Tabel 4. Pengukuran sifat fisik kulit tersamak terdiri dari kekuatan tarik, kemuluran dan ketahan zwik yang mengacu kepada ISO 3376:2011 tentang pengukuran sifat fisik kulit tersamak. Hasil penelitian menunjukkan bahwa kualitas kulit tersamak memenuhi standar. Pengukuran fisik kulit tersamak merupakan salah satu parameter yang penting dalam menentukan kualitas kulit samak, karena dapat mengambarkan kekuatan ikatan antara serat kolagen penyusun kulit dengan zat penyamak yang digunakan. Hasil pengukuran kekuatan tarik dipengaruhi oleh jaringan serat kolagen kulit dan struktur fisik dan kimiawi kulit yang akan disamak.

Menurut Kasim et al. (2012) warna kulit menghasilkan kulit tersamak berwarna sesuai dengan bahan penyamak yang digunakan. Warna kulit tersamak pada menghasilkan warna coklat. Pengamatan terhadap sifat fisik kulit tersamak juga meliputi penilaian terhadap organoleptis. Pada Tabel 5 terdapat hasil pengamatan organoleptis kulit tersamak dengan ekstrak tanin dari A. auriculiformis.

Pengujian organoleptis merupakan pengujian dengan menggunakan panca indera dan pengamatannya secara visual. Hasil pengamatan kulit tersamak menghasilkan kulit yang memenuhi standar ditinjau dari pengamatan pada nerf, bagian daging dan keadaan kulit.

\section{KESIMPULAN}

Dari hasil penelitian dapat disimpulkan bahwa kulit kayu A. auriculiformis mengadung kadar air 10,59\%, bahan larut air 32,74\%, dan kadar tanin 30,84\%. Berbagai metode ekstraksi yang digunakan diperoleh rendemen ekstrak tertinggi dengan metode autoclave selama 40 menit yaitu 29,65\% dengan kadar tanin ekstrak $52,79 \%$. Sementara kadar tanin ekstrak tertinggi diperoleh dengan metode microwave selama 3 menit yaitu 54,09\%. Ekstrak kulit kayu $A$. auriculiformis berpotensi dan dapat digunakan sebagai bahan penyamak kulit. Hasil analisis kulit tersamak telah memenuhi standar. Analisis kimia kulit tersamak diantaranya kadar tanin terikat $30,98 \%$ dan derajat penyamakan kulit $70,74 \%$. Sedangkan pengukuran sifat fisik adalah kekuatan tarik $254,21 \mathrm{~kg} / \mathrm{cm}^{2}$, kemuluran $63,95 \%$, kekuatan zwik 9,27 mm (nerf tidak retak), ketebalan 0,9 mm dan berwarna coklat.

\section{UCAPAN TERIMA KASIH}

Terimakasih kepada Dikretorat Jenderal Pendidikan Tinggi (DIKTI) dan Lembaga Pengelolaan Dana Pendidikan (LPDP) yang telah membiayai penelitian ini melalui Beasiswa BUDI- DN Tahun 2017.

\section{DAFTAR PUSTAKA}

Haroun, M., Khirstova, P., \& Covington, T. (2013). Analysis of commercial vegetable tannin materials and related polyphenols of selected Acacia species in Sudan. Journal of Forest Products \& Industries, 2(1), 21-28.

Herminiwati, Waskito, S., Purwanti, C. M. H., Prayitno, \& Nigsih, D. (2015). Pembuatan bahan penyamak nano nabati dan aplikasinya dalam penyamakan kulit. Majalah Kulit, Karet, dan Plastik, 31(1), 15-22. https://doi.org/10.20543/mkkp.v31i1.180

Hussein, S. A. (2017). Utilization of tannins extract of Acacia seyal bark (Taleh) in tannage of leather. Journal of Chemical Engineering \& Process Technology, 8(3). https://doi.org/10.4172/2157- 
7048.1000334

Iriany, F. P. (2017). Ekstraksi tanin dari kulit kayu akasia dengan menggunakan microwave: Pengaruh daya microwave, waktu ekstraksi dan jenis pelarut. Jurnal Teknik Kimia USU, 6(3), 5257.

Kasim, A., Nurdin, H., \& Mutiar, S. (2012). Aplikasi gambir sebagai bahan penyamak kulit melalui penerapan penyamakan kombinasi. Jurnal Litbang Industri, 2(2), 55-62. https://doi.org/10.24960/jli.v2i2.600.55-62

Kasim, A., Novia, D., Mutiar, S., \& Pinem, J. (2013). Karakterisasi kulit kambing pada persiapan penyamak dengan gambir dan sifat kulit tersamak yang dihasilkan. Majalah Kulit, Karet, dan Plastik, 29(1), 1-12. https://doi.org/10.20543/mkkp.v29i1.213

Kasim, A., Asben, A., \& Mutiar, S. (2015). Kajian kualitas gambir dan hubungannya dengan karakteristik kulit tersamak. Majalah Kulit, Karet dan Plastik, 31(1), 55-64. https://doi.org/10.20543/mkkp.v31i1.220

Kasim, A., \& Mutiar, S. (2016). Penyamakan kulit kambing untuk memperoleh kulit tersamak berkekuatan tarik tinggi melalui penyamakan kombinasi. Prosiding Seminar Nasional Kulit, Karet dan Plastik ke-5, 5(1).

Liao, J., Qu, B., Liu, D., \& Zheng, N. (2015). New method to enhance the extraction yield of rutin from Sophora japonica using a novel ultrasonic extraction system by determining optimum ultrasonic frequency. Ultrasonics Sonochemistry, 27 ,

$110-116$. https://doi.org/10.1016/j.ultsonch.2015.05.005

Lokeswari, N. \& Sujatha, P. (2011). Isolation of tannins from Caesalpinia coriaria and effect of physical parameters. International Research Journal of Pharmacy, 2(2), 146-152.

Mahdi, H., Palmina, K., \& Glavtch, I. (2006).
Characterization of Acacia nilotica as an indigenous tanning material of Sudan. Journal of Tropical Forest Science, 18(3), 181-187.

Musa, A. E., \& Gasmelseed, G. A. (2013). Development of eco-friendly combination tanning system for the manufacture of upper leathers. International Journal of Advance Industrial Engineering, 1(1), 9-15.

Ogino, H., Otsubo, T., \& Ishikawa, H. (2008). Screening, purification, and characterization of a leather-degrading protease. Biochemical Engineering Journal, 38(2), 234-240. https://doi.org/10.1016/j.bej.2007.07.008

Rhazi, N., Hannache, H., Oumam, M., Sesbou, A., Charrier, B., Pizzi, A., \& Charrier-El Bouhtoury, F. (2014). Green extraction process of tannins obtained from Moroccan Acacia mollissima barks by microwave: Modeling and optimization of the process using the response surface methodology RSM. Arabian Journal of Chemistry. https://doi.org/10.1016/j.arabjc.2015.04.032

Suparno, O., Covinton, A. D., \& Evans, C. S. (2008). Teknologi baru penyamakan kulit ramah lingkungan: Penyamakan kombinasi menggunakan penyamak nabati, naftol dan oksazolidin. Jurnal Teknologi Industri Pertanian, 18(2), 79-84.

Suseno, N., Adiarto, T., Dalton, A., \& Tendean, P. (2014). Ekstraksi tanin dari kulit kayu pinus sebagai bahan perekat briket. Prosiding Seminar Nasional Rekayasa Kimia dan Proses 2014.

TAPPI, S. M. (1996). TAPPI Standards: Regulations and style guidelines. Atlanta, USA: TAPPI Press.

Wina, E., Susana, I. W. R., \& Tangendjaja, B. (2010). Biological activity of tanins from Acacia mangium bark extracted by different Solvents. Media Peternakan, 33(2), 103-107. https://doi.org/10.5398/medpet.2010.33.2.103 
